\title{
Consonant-Final Loanwords and Epenthetic Vowels in Italian*
}

\author{
Lori Repetti
}

Stony Brook University, NY. Department of Linguistics

lori.repetti@stonybrook.edu

\begin{abstract}
The quality of an epenthetic vowel in a particular language may vary depending on segmental and prosodic factors, such as the quality of the surrounding consonants, the quality of other vowels in the word, and the position of the epenthetic vowel within the word. This last factor has received little attention in the literature. I have identified a number of cases in Italian in which the quality of the inserted vowel is determined by its position within the word. Through an in-depth study of loan word integration we see that the choice of the inserted vowel is influenced not only by phonology, but by phonetics and morphology as well.
\end{abstract}

Keywords: epenthesis; epenthetic vowel quality; paragoge; Italian.

\section{Table of Contents}

\section{Introduction}

2. Epenthetic vowel quality

3. Non-final epenthetic vowels in Italian
5. Linking elements in compounds and affixoids

6. Conclusions

References

4. Paragogic vowels in Italian

\section{Introduction}

An epenthetic vowel is a vowel inserted into a phonological environment to repair a marked or illegal structure. The epenthetic vowel in a given language is usually assumed to be a default vowel, defined as the unmarked or perceptually least salient

* I would like to thank my informants for their time and patience, and Mark Aronoff, Anna Cardinaletti, Laura Minervini, Anna Thornton, the reviewers for the Catalan Journal of Linguistics, and especially Miran Kim for their comments and help with this paper. Needless to say, all errors remain my own. 
vowel. Recently, this assumption has been examined more closely, and a much richer picture emerges: epenthetic vowel quality varies widely both within a single language as well as cross-linguistically.

I have identified a number of cases in Italian in which the quality of the epenthetic vowel is determined not only by segmental factors (copy vowel, default vowel, quality of nearby vowels and/or consonants), but by the position of the epenthetic vowel within the word (word-final, non-word-final). ${ }^{1}$ I propose the following for Italian:

(1) Epenthetic vowel quality in Italian:

a. The epenthetic vowel used in non-word-final position is the default vowel, [i].

b. The quality of the inserted vowel in word-final position is influenced by phonetics and morphology, and is not [i].

By studying the integration of consonant-final loan words, which undergo final vowel epenthesis in Italian, a richer picture of the interaction among the various components of grammar emerges.

In this article I analyze data from many varieties of Italian, including standard Italian, regional varieties of Italian, American varieties of Italian, and Old Italian; relevant data from Italian dialects support the analysis. The paper is organized as follows. In $\S 2$ I briefly review the literature on epenthetic vowel quality. In $\S 3$ I discuss cases of epenthesis in non-word-final position in Italian. In §4, word-final non-etymological vowels are discussed: final [e] is argued to be part of the release of the word-final consonant (\$4.1); final [o]/[a]/[e]-insertion is an example of morphological integration $(\$ 4.2)$; [o]-epenthesis is used when a morphologically neutral vowel is needed $(\$ 4.3)$. This last point is supported by data involving compounding and affixation $(\$ 5)$.

\section{Epenthetic vowel quality}

It has often been assumed that the epenthetic vowel in a particular language is either a copy vowel, an unmarked vowel, or a non-salient «default» vowel; however, this is not always the case (Kitto \& de Lacy 1999, Lombardi ms, Rose \& Demuth 2006, Uffmann 2006). Highly marked vowels, such as front rounded vowels, can be the epenthetic vowel in some languages (Hume \& Bromberg 2005). Hume \& Bromberg (2005: 3) claim that the epenthetic vowel in any given language is «the vowel with the lowest information content»; hence, «unmarked» vowels (like schwa) as well as «marked» vowels (like front rounded vowels) can be epenthetic vowels in different languages. There is also much variation in the realization of the quality of the epenthetic vowel within a given language. Variation in epenthetic vowel qual-

1. The term pro(s)thesis refers to word-initial epenthesis, anaptyxis is word-medial epenthesis, and paragoge is the process of word-final vowel insertion. 
ity is determined by many factors, including the quality of nearby vowels and/or consonants (Kitto \& de Lacy 1999, Uffmann 2004, 2006).

Many languages have more than one epenthetic vowel. For example, Fula has two epenthetic vowels: [i] and [u] (Paradis 1992); Pijin epenthetic vowels include copy vowels, [i], and [e] (Avram 2010). Steriade (1995: 138) argues that if a language has two epenthetic vowels, the choice between them may be lexically determined.

In the following paragraphs we see that Italian, like Fula and Pijin, has more than one epenthetic vowel: the default vowel [i], the marked vowel [o], and a central vowel which displays great intra- and inter-speaker variation.

\section{Non-final epenthetic vowels in Italian}

In Italian, the epenthetic vowel most commonly used to satisfy phonotactic constraints in non-word-final position is [i]. (The epenthetic vowels in the examples below are underlined.)

The vowel most often identified as the non-final epenthetic vowel in Italian is [i]. Prosthetic [i] has been used before word-initial /s/ + consonant clusters since the $13^{\text {th }}$ century (istamane 'this morning'), although today the use of [i] in these contexts is limited to literary forms of the language and formal spoken Italian (in [i ]Svizzera 'in Switzerland') (Renzi 1993: 222, Maiden 1995: 47). Prosthetic [i] is found occasionally before initial [n] ([(i)nnókko] 'dumpling' Maiden 1995: 47), as well as sporadically in other contexts ([(i)ddío] 'God' Rohlfs 1966: 203). (See also Sampson 2010.)

Word-medially, [i] was used as the epenthetic vowel in Old Italian: Latin asthma > asima 'asthma' (Renzi 1993: 222). Other evidence of the use of anaptyctic [i] comes from non-standard varieties of Italian, including popular Italian (atmosfera [atimosféra] 'atmosphere', pneumatico [pineumátiko] 'tire', psicologo [pisikólogo] 'psychologist') and American varieties of Italian (box [bókisa]) (Menarini 1939: 155). ${ }^{2}$

Renzi (1993: 222) reports two other epenthetic vowels sporadically used in the history of Italian: [a] and [e]. In Old Italian, epenthetic [e] was occasionally used word-medially (cif( $\underline{\text { e }}$ ra 'digit'), and epenthetic [a] is rarely attested before wordinitial $r$ : (a )rricordare 'to remember'. (See also Sampson 2010.)

Another type of epenthetic vowel not discussed in the literature on Italian is a copy vowel. ${ }^{3}$ We find copy vowels used in the integration of English loans in American varieties of Italian. In the data below we see that the epenthetic vowel used word-internally is a copy of the preceding vowel (if there is one) or of the following vowel. ${ }^{4}$

2. I report the quality of the stressed mid vowels of loanwords as lax (Kenstowicz 2010), although the tenseness may vary.

3. Copy vowels are well-known in other Romance languages, such as Sardinian. For example, Jones (1997: 376) explains that Sardinian copy vowels are inserted in «absolute final position» with consonant-final words: /andamuz/ > [andámuzü] 'we go'.

4. I have excluded cases of epenthetic [i] in (2). There is evidence that [i] may be the «default» epenthetic vowel in these varieties of Italian. For example, the epenthetic vowel in box [bókisa] 
(2) copy vowel epenthesis in American varieties of Italian

chestnuts [t $\int$ estenótto] (Menarini 1939: 157)

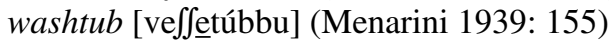

cocktail [kokkotéclla] (Menarini 1939: 159)

trouble [trúbbulu] (Menarini 1939: 155)

popcorn [pappakórno] (Danesi 1985: 48)

slap [saláppi] (Menarini 1939: 155)

To summarize, the literature reports the following distribution of non-final epenthetic vowels in varieties of Italian. ${ }^{5}$

(3) epenthetic vowel distribution

word-initial: [i]; less frequently [a]

word-medial: [i]; less frequently [a], [e], and copy vowel

This inventory of epenthetic vowels is quite common cross-linguistically. I propose that [i] is the «default» vowel used in most varieties of Italian, with a copy vowel also used in American varieties, while [a] and [e] are rarely-attested historical variants.

\section{Paragogic vowels in Italian}

We now turn to the main topic of this article: word-final epenthesis with consonant-final loan words. While most consonant-final loans in standard Italian today are integrated without a final vowel (Dardano 1986, Klajn 1972, Savard 2007), a paragogic vowel may be inserted since «[t]he native lexicon of Italian is characterized by the nearly total absence of consonant ending words» (Passino 2005: 1). The use of a final epenthetic vowel in this context is most common in older varieties of Italian (Renzi 1993: 222; Rohlfs 1966: 467-468), varieties of Italian spoken abroad (Repetti 2006, 2009), «regional and diastratically low varieties of Italian» (Passino 2005: 108), especially those spoken in Tuscany and Rome (Dressler \& Thornton 1996: 8). In this section, we see that a wide variety of vowels is used in this context: $[\mathrm{e}](\S 4.1),[\mathrm{o}] /[\mathrm{a}] /[\mathrm{e}](\S 4.2),[\mathrm{o}](\S 4.3)$.

(Menarini 1939: 155) cannot be considered a copy vowel, and must be a default epenthetic vowel. There are numerous examples with an anaptyctic [i] that can be analyzed either as a copy vowel or as a default epenthetic vowel: business [bisinísse] (Danesi 1985: 51), tulips [tulípinsi] (field work), fix [fíkịsi] (Menarini 1939: 155), picnic [pikinníkko] (Seneca 1927: 43), socks [sákịsi] (Menarini 1939: 157), tips [típisi] (Menarini 1939: 157), sleep [silíppi] (Menarini 1939: 155), clams [klémịsi] (Menarini 1939: 155).

5. Krämer (2009: 110) identifies $e$ as «[t]he most plausible candidate for an epenthetic vowel» in Italian, while Rando (1970: 141, note 12) calls $e$ a «neutral vowel both phonetically and morphologically.» 


\subsection{Paragogic [e] (or [a] or [])}

Paragogic [e] was used in early varieties of Italian with consonant-final words: David(e $)$ 'David' (Renzi 1993: 222; Rohlfs 1966: 467-468), ${ }^{6}$ and it is used today in regional and popular varieties of Italian. ${ }^{7}$

Nearly all discussions of word-final epenthesis with consonant-final loans report [e] as the epenthetic vowel: stop [stóppe] (Passino 2005 and references therein, as well as Bafile 1999, Bertinetto \& Loporcaro 2005, Lepschy \& Lepschy 1981: 64, Rando 1970). However, the realization of the post-consonantal vowel sound varies from speaker to speaker, from region to region, and from context to context. Some transcribe the range of final epenthetic vowel quality as $[\mathrm{e}] \sim[ə] \sim$ [] (stop [stóppe], [stóppo] ], [stóppํ]), with the latter two forms described as having a «reduced» final vowel (Bertinetto 1985, Hurch \& Tonelli 1982, Klajn 1972).

While it is not surprising to find [e] or [ə] or [ $\left.{ }^{\circ}\right]$ employed as the default epenthetic vowel, it is surprising that the quality of the epenthetic vowel identified for non-final position - [i] - differs from the epenthetic vowel identified for final position $-[\mathrm{e}] /\left[{ }^{0}\right] /\left[^{\circ}\right]$. In most discussions of epenthesis, within a given language the quality of the epenthetic vowel may vary depending on segmental environment, but little mention has been made of position within the word as a determining factor.

In the following paragraphs, I discuss the possible motivations for using [e]/ $[ə] /\left[{ }^{\circ}\right]$, as opposed to [i], as the paragogic vowel. I first discuss the phonetic characteristics of this vowel (\$4.1.1) and suggest a phonological analysis (\$4.1.2). I then address morphological considerations (\$4.1.3).

\subsubsection{Phonetic characteristics of paragogic [e]}

Recent research has focused on the phonetic characteristics of epenthetic vowels. Epenthetic vowels are often assumed to be phonetically identical to lexical vowels, and some studies have shown that this is in fact the case. For example, Kim \& Kochetov (2011) conclude that the epenthetic vowel used in loanwords in Korean is identical in spectral and durational properties to native high vowels. However, this is not always the case. Gouskova \& Hall (2009) show that the phonetic properties of the epenthetic vowel used in final CC clusters in Lebanese Arabic differ from those of the lexical vowel: epenthetic [i] is shorter and more back than lexical [i].

In order to better understand the nature of the word-final epenthetic vowel in Italian, I conducted a study to compare the quality of final epenthetic $[\mathrm{e}] /\left[{ }^{\partial}\right] /\left[^{\circ}\right]$ with unstressed lexical [e] in word-final position. I elicited paragogic vowels in consonant-final loans and lexical vowels in native words. The goal of the study was to determine if the two sets of final vowels are identical or if there are acoustic differences between them. The participants consisted of five native speakers of Italian

6. Old Italian and regional varieties of Italian often insert paragogic [e] with vowel-final oxytones: più [pjúe] 'more'.

7. Words ending in a single consonant generally undergo gemination when followed by a final epenthetic vowel (tram [trámme] 'tram'), a vowel-initial suffix (jeep + one > [dzippóne] 'big jeep'), or a vowel-initial word (tram azzurro [trámm addzúrro] 'blue tramway'). See Passino (2005) for a detailed discussion of this phenomenon, and Repetti (2009) for an alternative analysis. 
( 2 men and 3 women) who were born and educated in Italy; 4 of the 5 currently live in the United States. Two are from Tuscany, the others are from Campania, Sicily, and Piedmont.

The experiment involved three short tasks. The first task involved reading a phrase consisting of a determiner + noun in Italian and providing the plural form of the noun. The informant was instructed to read the prompt out loud and to provide the plural form of the noun. The test consisted of 25 words, of which 4 were wellknown consonant-final loans (tram, stop, quiz, computer), 11 were [e]-final lexical items, and the rest were fillers.

(4)

un nipote / due

ANSWER: 'nipoti'

'one nephew / two

The target words included the 4 consonant-final loans and the 11 [e]-final nouns. I collected the first noun in the pair and examined the phonetic characteristics of the end of the word. For example, the acoustic features at the end of a consonant-final loan word like tram (which is reported to be pronounced in a variety of ways: $[\operatorname{tram}] /[$ tramme] $/[$ tramme] $/[$ tramm] $]$ ) were compared to the [e] of an [e]-final noun that is part of the native lexicon, such as fiamme [fjámme] 'flames'. In this way, I was able to see if the vocalic element which may follow consonantfinal loans is identical to the final [e] of nouns that are part of the native vocabulary.

The second task involved reading 11 sentences in Italian. In each sentence, a function word was missing, and the informant was asked to select the correct function word from a choice of two. Five of the 11 sentences contained a wellestablished consonant-final loanword (jazz, rock, blitz, help, spot) followed by another word beginning with a stop consonant, and three had an [e]-final noun followed by a word-initial stop consonant.

(5) Mi piace il jazz degli anni Sessanta, ma non (il / la) rock degli anni Ottanta.

ANSWER: 'il'

'I like the jazz of the 1960s, but not the rock of the 1980s'

Similar to task 1, I collected the consonant-final loans and [e]-final nouns, measured the ends of each word, and compared the two sets.

The final task involved reading a pair of words in Italian and indicating if they rhymed or not. Seven of the 15 pairs contained a common consonant-final loan word, and 7 consisted of an [e]-final noun.

(6)
cane / pane
ANSWER: 'yes'
'dog / bread'

The first word of the relevant pairs was the target word (consonant-final or [e]-final), and, as with the previous two tasks, I measured and compared the ends 
of the consonant-final loans and [e]-final nouns. This test also had another purpose, namely, to see if native speakers judged the consonant-final loans (which are reported to be pronounced with final epenthetic $[\mathrm{e}] /\left[{ }^{\circ}\right] /\left[{ }^{\circ}\right]$ ) as rhyming with $[\mathrm{e}]$-final nouns. For example, did they analyze tram, which is reported to be pronounced $[$ tram $] /[$ tramme] $] /[$ tramm $\underline{\underline{\imath}}] /\left[\right.$ tramm$\left.^{2}\right]$, as rhyming with fiamme [fjamme] 'flames'? (See $\$ 4.1 .2$ for further discussion.)

The comparison of the consonant-final loans with native nouns ending in a lexical [e] yielded surprising results. As expected, most consonant-final loans were pronounced without a paragogic vowel (in other words, consonant-final loans were pronounced with a final consonant). However, some were pronounced with a post-consonantal vocalic element. The surprising finding is that the spectral properties and duration of the post-consonantal vocalic element were not similar to the spectral properties and duration of final lexical [e]. The results show great intra- and inter-speaker variation in the quality of the paragogic vocalic element, but not in the quality of the lexical vowels.

The figure in (7) shows the formant chart for lexical and paragogic vowels for one speaker (speaker 3, female). The stressed lexical vowels are indicated as white vowels in black circles, and the unstressed lexical vowels are indicated as black vowels in white circles. The final epenthetic vocalic elements are indicated as stars, with the average indicated as a gray «V». We can clearly see that the inserted vowel is close to (but not identical to) unstressed lexical [e].

(7) formant chart for speaker 3 (female) showing word-final post-consonantal vocalic elements (as stars) and lexical vowels (in circles)

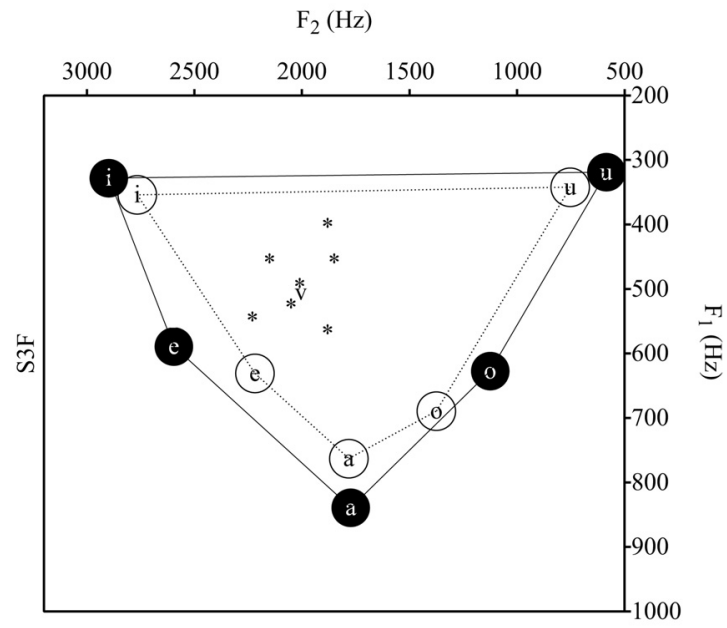

Formant chart (Hertz)

For some speakers, such as speaker 2 (female), the inserted vowel is more central; however, it does not bear any rounding, so it is perceptually closest to [e]. 
(8) formant chart for speaker 2 (female) showing word-final post-consonantal vocalic elements (as stars) and lexical vowels (in circles)

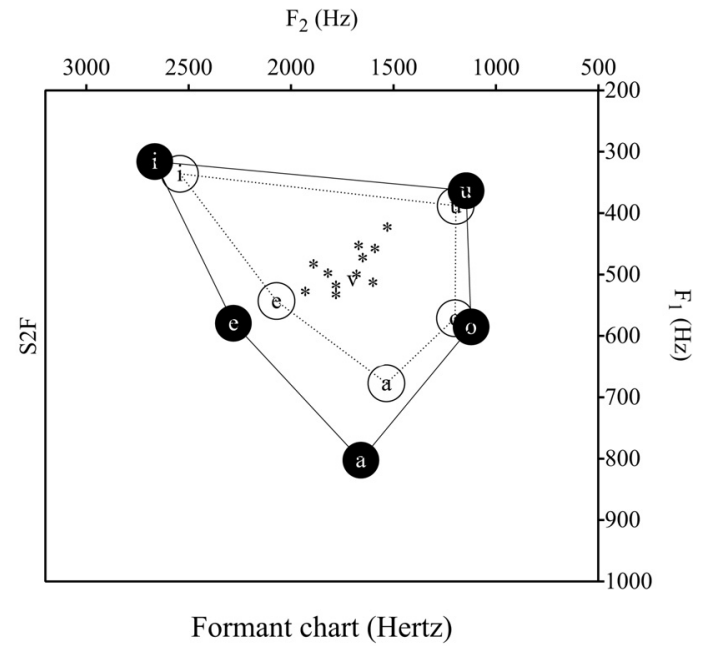

In the table in (9), we see the duration of unstressed final mid vowels averaged for all speakers. The first column shows the duration of the lexical vowels, and the right column indicates the duration of the inserted vocalic elements. Clearly, the inserted vowel is much shorter than the lexical vowel. ${ }^{8}$

(9) mid-vowel duration in unstressed final position: lexical vowels and inserted vowels

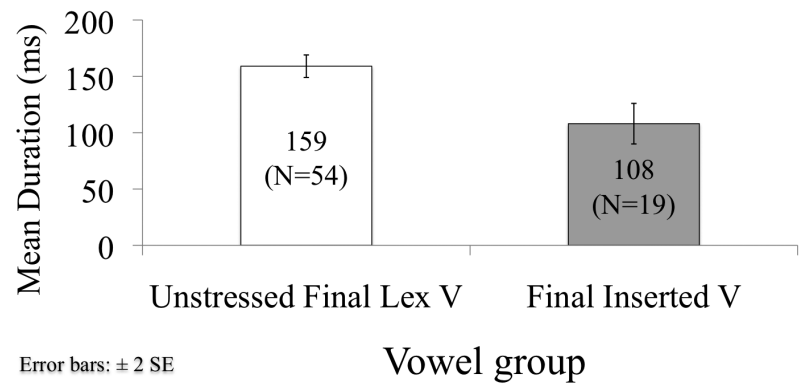

The results of this experiment confirm the wide range of variation in the pronunciation of words ending in a consonant: most speakers had no vocalic element in

8. For vowel duration in Italian, see D'Imperio \& Rosenthall (1999), Hajek et al. (2007), Vayra et al. (1999). 
post-consonant position, others had a central vowel, and other produced a vowel close to lexical [e]. While none of the speakers produced a paragogic vowel identical to final lexical [e], for all speakers who produced a paragogic vowel at all, its phonetic characteristics were more similar to word-final lexical [e] than to any other word-final lexical vowel (in particular, [i], the 'usual' epenthetic vowel in Italian). These findings confirm the impressionistic description of the paragogic vowel as [ $\left.{ }^{\circ}\right]$, [ə], or [e].

While the purpose of this paper is to examine the quality of epenthetic vowels in Italian, it is natural to question why an epenthetic vowel is needed in the first place. I propose that the vocalic element realized in word-final post-consonantal position, with all of the phonetic variation noted above, is produced as part of the release of the word-final consonant. Henderson \& Repp (1982: 80) identify five categories of consonant release: a consonant can be unreleased, silently released, inaudibly released, weakly released, or strongly released. The word-final consonants in the cases that I studied clearly cover all categories. In some cases there was no release at all, while in others the final consonant was released but with no vowel formants visible. The more relevant cases involved consonantal release followed by a vowel of short duration with schwa-like formants, and consonantal release followed by a full vowel with stable formants and duration comparable to a lexical vowel. Therefore, the impressionistic descriptions of consonant-final loans as ending in $\left[^{\circ}\right]$ and $[ə]$ can be interpreted as words ending in a released consonant followed by a central schwa-like vowel, while the descriptions of the paragogic vowel as [e] can be interpreted as words ending in a released consonant followed by a full vowel similar to [e].

I follow Hudson (2001) who, arguing against a syllable-based analysis of Amharic epenthesis, proposes a «release» account of epenthesis: «epenthesis may be understood as making consonant release possible in the absence of a following vowel» (Hudson 2001: 70; see also Hudson 1995). The vocalic element following consonant-final loans in Italian is actually the result of the release of the consonant. ${ }^{9}$

\subsubsection{Phonological analysis of paragogic [e]}

What is the phonological status of the final vocalic element realized with consonant-final loans? I propose that, in the cases I studied, this vocalic element does not play a phonological role. ${ }^{10} \mathrm{I}$ base this proposal on two observations. First, there is great variation in the phonetic realization of the final vowel. The final vocalic element is always a central vowel close to [e], but, while final lexical [e] has stable

9. While the consonant-release explanation can successfully account for the cases described above, it cannot explain the epenthesis process with vowel-final oxytones (più [pjúe] 'more') attested in Old Italian and Tuscan varieties of Italian. Here, too, there is great intra- and inter-speaker variation. I propose that the final vowel used in this context to avoid word-final stress is a mid vowel which is phonetically close to lexical [e] and is reinterpreted as such. An investigation into the phonetic properties of this vowel is reserved for future research.

10. Anecdotally, native speakers of Italian do not perceive a final vowel in consonant-final words when they are uttered by themselves or by other native speakers of Italian; however, native speakers of English often do hear a vowel in consonant-final words uttered by Italian native speakers. The debate over the role of perception and production in loan word adaptation is beyond the scope of this paper. 
formants, the post-consonantal vowel has great variability in its realization. Second, the goal of task 3 (the rhyming word test) was actually two-fold. I paired some consonant-final loans with [e]-final words to see if the informant identified them as rhyming words. I used words with final lexical [e] preceded by both singleton and geminate consonants, such as tram/fame [tram]/[fáme] 'tram/hunger' and tram/ fiamme [tram]/[fjámme] 'tram/flames'. If the post-consonantal vocalic element in tram played a phonological role, the speakers might identify these pairs as rhyme words. Significantly, no one identified pairs like these as rhyming.

Further support for the non-phonological role of the epenthetic vowel comes from the fact that, in some varieties of Italian, it does not participate in stress assignment processes. It is very common cross-linguistically for epenthetic vowels to be invisible to stress assignment (Alderete 1999, Broselow 1999, Hagstrom 1997). The same phenomenon is attested here. In Italian, stress usually falls on one of the last three syllables of a word, but antepenultimate stress is blocked if the penultimate syllable is heavy: *[ká.pit.ta]. However, Rohlfs (1966: 467) reports the popular pronunciation lápisse (< lápis) 'pencil' with antepenultimate stress, a heavy penult, and a final epenthetic vowel. ${ }^{11}$

It is well-known that phonologically active «epenthetic» vowels are different from «intrusive» or «excrescent» vowels (phonologically invisible) (see Hall 2006, 2011 for an overview). The latter «are noticeably phonetically weaker than other vowels... are short in duration and centralized in quality... may have a quality not present in the language's lexical vowel system» (Hall 2011: 1584). I propose that the word-final post-consonantal vowel described here for Italian is a kind of phonologically inert excrescent vowel.

There are some differences between what has been described in the literature as excrescent vowels and the word-final post-consonantal vowels in Italian. First, excrescent vowels are found in inter-consonantal position, while in Italian they are word-final. Second, excrescent vowels are the result of the retiming of consonant gestures, while the Italian vowels are the result of a different phonetic process: consonant release.

For the participants in the experiment described above, the post-consonantal vocalic element does not appear to play a phonological role. However, we can assume that for some Italian speakers, paragogic [e] is part of the phonological representation of the word. ${ }^{12}$ We know that historically with some well-integrated loans, paragogic [e] was phonologized. For example, the English word punch ('drink'), first attested in Italian with this spelling in 1813 (Cortelazzo \& Zolli

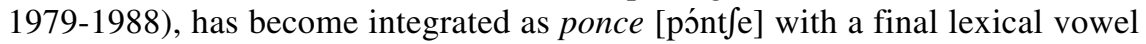
reflected in the spelling of the word (Dressler \& Thornton 1996: 9). Furthermore,

11. Passino (2005: 8, from Graziuso 1988) reports similar stress patterns in Italian dialects: Salentine còrnerre < 'corner', pòkerre < 'poker'.

12. In some Italian dialects, the epenthetic vowel fully participates in the stress assignment process. In the following examples reported by Passino (2005: 8), a consonant-final word undergoes paragoge and consonant gemination; crucially, stress shifts to the heavy penultimate syllable to conform to the new metrical structure. In Abruzzese: Tárzan (proper name) > Tarzánnə; in Neapolitan Ėnel (acronym) > Enèlla, Àtan (acronym) > Atànna, Càremar (abbreviation) > Caremàrra. 
humorous sonnets produced in a Tuscan variety (Sienese), have consonant-final loan words with paragogic [e] (stock [stókke]) rhyming with native words ending in lexical [e] (brocche [brókke] 'carafes'). ${ }^{13}$

\subsubsection{Morphological considerations in word-final [e] epenthesis}

Consonant-final nouns are invariable in Italian: film 'film/films' ${ }^{14}$ This is not surprising, since cross-linguistically «borrowings that do not fit the phonological pattern of any noun class are likely to be indeclinable» (Aronoff 1994: 126). In this section, we question the morphological role of the epenthetic vowel following consonant-final loans.

If the vocalic element following a consonant-final loan does not play a phonological role, it clearly does not play any morphological role either. In other words, a consonant-final noun like tram is analyzed morphologically and phonologically as /tram/, but an excrescent $[\mathrm{e}] /\left[{ }^{\circ}\right] /\left[^{\circ}\right]$ may be realized after the final consonant: [tramme] $] /[$ tramme] $] /[$ tramme] .

For those speakers for whom the final epenthetic [e] is phonologized, we can ask what its morphological role is. Nearly all of the words identified in the literature as utilizing a final epenthetic vowel are nouns, and there are two classes of nouns utilizing the /e/ suffix in the singular form.

The first possibility is that epenthetic [e] might be analyzed as an invariable suffix, meaning the loan belongs to a class in which the singular and plural forms are identical: stele/stele [stéle] 'stone/stones' ${ }^{15}$ It is important to note in this context that invariable nouns form the most productive class of nouns in Italian today (D'Achille \& Thornton 2003, Dressler \& Thornton 1996). This seems the most likely morphological analysis of consonant-final loans with epenthetic [e], since nouns like [tramme] are, in fact, always invariable (Dressler \& Thornton 1996: 8).

The second possibility is that loans ending in epenthetic [e] are part of a class of nouns which uses an [e] suffix in the singular and an [i] suffix in the plural: cane/ cani [káne]/[káni] 'dog/dogs'. Perhaps epenthetic [e] is analyzed as a marker of this class. For standard and non-standard varieties of Italian spoken in Italy today, this is clearly not the case: Dressler \& Thornton (1996: 8) report that consonant-final nouns with a final epenthetic [e] do not inflect for number. Furthermore, D'Achille $\&$ Thornton (2003) report that the inflection class containing the $e / i$ set of suffixes is not productive in Italian today. (However, see $\S 4.2$ for a discussion of this type of epenthesis in older varieties of Italian and American Italian.)

I propose that the morphological classification of nouns like tram varies from speaker to speaker: this word may belong to the class of invariable consonant-final nouns or invariable $e$-final nouns.

13. This example is from the sonnet «Il test» by Silvia Golini (www.sonetto.org). Thanks to one of the reviewers for bringing this to my attention.

14. Dressler \& Thornton (1996: 7-8) report isolated cases of recent consonant-final loans that are consonant-final in the singular, and have an [i] suffix in the plural: toast/tosti [tóst]/[tósti] 'toast/ toasts' (with a spelling change in the plural), film/filmi [film]/[filmi] 'film/films'.

15. Borrowed nouns ending in lexical [e] are invariable: kamikaze [kamikátstse] 'kamikaze/kamikazes' (D’Achille \& Thornton 2003, Dressler \& Thornton 1996). 


\subsection{Word-final [o]/[a]/[e] epenthesis}

In earlier varieties of Italian as well as American varieties of Italian, word-final consonants are not tolerated, so a vowel is epenthesized word-finally with consonant-final loans. The quality of the vowel used with nouns varies depending, in part, on the gender of the noun. ${ }^{16}$ Some masculine nouns have a final [o] added and are assigned to inflection class I (/o/ suffix in the singular and /i/ in the plural); feminine nouns generally have a final [a] added and are assigned to inflection class II (/a/ suffix in the singular and /e/ in the plural). Rarely, nouns of both genders receive a final [e] and are assigned to inflection class III (/e/ suffix in the singular and /i/ in the plural). The final [e] in these cases is different from the epenthetic [e] described above in $\$ 4.1$. This [e] represents a morpheme that allows the loan to be assigned to a particular declension class. ${ }^{17}$

(10) $[\mathrm{o}] /[\mathrm{a}] /[\mathrm{e}]$ epenthesis with consonant-final loans (nouns)

a. American varieties of Italian (Danesi 1985):

[o] mas. bill $>$ [bíllo]

[a] fem. rug $>$ [rágga]

[e] mas. business $>$ [bisinísse]

fem. furnace $>$ [fornáte $]$

b. pre-modern Italian:

[o] mas. Arabic kaff $>$ [káffo] 'odd number'

[a] fem. English beef steak $>$ [bistékka]

[e] mas. Arabic: julaab $>$ [ḑulćbbe] 'syrup'

fem. French: gaffe $>$ [gáffe] ${ }^{18}$ 'gaffe'

The same patterns are found with consonant-final adjectives: [o]/[a] is epenthesized to the end of a consonant-final adjective, and the adjective belongs to the class of adjectives with four inflectional suffixes ([o]/[a] singular, [i]/[e] plural). In standard Italian, as far as I am aware, no consonant-final borrowed adjectives have an [e] added ([i] plural), and there is only a handful of such cases reported for American Italian.

16. Dressler \& Thornton (1996: 22) and Thornton (2001) claim that gender determines inflection class assignment.

17. See Harris $(1991,1992)$ for a discussion of word markers in Spanish, and Acquaviva (2009) for Italian.

18. This is probably a spelling pronunciation, heard along with the more common [gaf]. 
(11) $[\mathrm{o}] /[\mathrm{a}] /[\mathrm{e}]$ epenthesis with consonant-final loans (adjectives)

a. American varieties of Italian (Danesi 1985):

[o]/[a] smart > [zmárto] (mas), [zmárta] (fem)

[e] cheap $>$ [t fíppe] 'mas $=$ fem'

b. pre-modern Italian:

[o]/[a] Frankish *snel > [znćllo] 'thin (mas)', [znćlla] 'thin (fem)'

[e] unattested

In these cases the need for a final vowel is both phonologically and morphologically motivated, but the choice of the vowel is determined by the morphology. The final vowel represents a morpheme that allows the loan to be incorporated into a particular inflection class. In the next section, we see another type of word-final epenthesis process that, I argue, is influenced by morphology.

\subsection{Word-final [o] epenthesis}

Quite strikingly, we find the use of final epenthetic [o] in contexts other than those described above in $\$ 4.2$. This is surprising because [o] is a marked vowel that is not usually used as an epenthetic vowel. In this section, I outline a number of cases of final [o]-epenthesis, and I review the previous accounts suggested in the literature. I then propose a morphology-based account of [o]-epenthesis.

In standard Italian we find [o]-paragoge historically with third person plural forms of the verb. The Latin verbal suffix /nt/ underwent loss of final /t/, leaving final $/ \mathrm{n} /$. Final $/ \mathrm{n} /$ is realized as such in Spanish third person plural verbs; however, in Italian a final epenthetic vowel was needed, and [o] was the vowel used.

(12) Latin: amant > *aman > [ámano] 'they love'

The standard explanation of the presence of [o] in this context has to do with analogy between the first person singular and third person plural forms of the verb 'to be' (Maiden 1995: 130-131; Rohlfs 1968: 255). In Latin, the inflectional morpheme for the first person singular form of the verb is /o/: /am+o/ 'I love'. This vowel was generalized to all first person singular forms, even if the (irregular) Latin form originally did not have one (13a). The third person plural form of the verb 'be' was segmentally similar to the first person singular form, and, because of this, the $[\mathrm{o}]$ of the first person singular was extended to the third person plural (13b).

(13) a. Latin: sum $>$ *son $>$ son+o 'I am'

b. Latin: sunt > *son > sono 'they are'

The final [o] of the third person plural form of this particular verb was then extended to all verbs (12).

While this explanation successfully accounts for this case, the phenomenon of [o]-paragoge is much more extensive. Other contexts in which a non-etymological 
[o] is inserted in final position include the lo allomorph of the masculine singular definite article in Italian (see Repetti 2008 for discussion), and many pronominal clitic forms in northern Italian dialects (see Cardinaletti \& Repetti 2007, 2008). Furthermore, in historical processes in other Romance languages, such as Istriot, Dalmatian, Lombard, and Venetian, we find [o] epenthesized word-finally when apocope resulted in unacceptable consonant clusters (or final [e] was substituted by [o]) (Bertoletti 2003, Loporcaro 2002, Zamboni 1988). The use of final [o] in masculine singular nouns and adjectives might be accounted for as above in $\$ 4.2$; however, we cannot invoke that morphological explanation to account for paragogic [o] with infinitives and adverbs.

(14) a. historical [o]-epenthesis with nouns and adjectives noun: $\quad$ generu $>$ *zendr $>$ zendro 'son-in-law' (Old Veronese) adjective: $\quad$ teneru $>*$ tend $r>$ tendro 'tender' (Old Veronese)

b. historical [o]-epenthesis with infinitives and adverbs infinitive: vendere $>*$ vendr $>$ vendro 'to sell' (Old Veronese) adverb: $\quad$ semper $>$ *sempr $>$ sempro 'always' (Claro)

Bertoletti (2003) suggests that this phenomenon is purely phonetic, suggesting perhaps that the final [o] does not have a morphological function; however, he does not address the issue of the quality of the final vowel. Zamboni (1988: 250) surmises that there might be «morphological reasons» for the use of [o] in these contexts, but he does not elaborate on this topic.

Why is paragogic [o] used in these contexts? The phonetic explanation suggested above in $\$ 4.1$ for final [e]-epenthesis - namely, that the vocalic element produced as part of the final consonant release is interpreted as [e] - cannot account for these cases since the vocalic element produced word-finally in post-consonantal position is most similar to a front vowel, not a back rounded vowel. In Cardinaletti \& Repetti $(2007,2008)$ a morphological explanation was proposed, which I adopt and expand upon here. Word-final position is a morphologically salient position in Romance languages, and word-final vowels are interpreted morphologically (Ferrari 2005). In order to allow for a neutral (or non-) interpretation of the wordfinal epenthetic vowel, the least marked vowel is used: [o]. Final [o] is the vocabulary item least specified in morphological features, the 'elsewhere' item, «the morphological free and neutral vowel» (Zamboni 1988: 254). Let us take the noun system as an example. If we assume a markedness hierarchy in which feminine is more marked than masculine, and plural is more marked than singular (Battistella 1990), we see that [o] is consistently associated with the least marked categories. In the inflected classes of nouns, the [o] suffix in nouns is only associated with masculine gender and singular number, both unmarked categories. ${ }^{19}$ On the other hand, final [i] (the «default» epenthetic vowel) marks plurality in both masculine nouns (capi 'heads', cani 'dogs') and feminine nouns (chiavi 'keys', ali 'wings'),

19. The only exception is feminine singular mano 'hand'. 
and final [e] (the paragogic vowel used productively in some varieties of Italian today) is associated with feminine nouns, both singular (chiave 'key') and plural (case 'houses') (as well as masculine singular nouns: cane 'dog'). ${ }^{20}$

Examples of final [o] which does not play a role in the inflection of the word in Italian include gerunds (parlando 'talking'), past participles (ho parlato 'I have spoken'), adverbs (poco 'a bit', molto 'very', tanto 'a lot', presto 'soon', dopo 'later', lento 'slowly'), quantifiers and indefinite pronouns and adjectives (altro 'other', uno 'one', ciascuno 'each one', tutto 'all', qualcuno 'some one', tanto 'a lot', poco 'a little', molto 'a lot'), negative pronouns and adjectives (nessuno 'no one'), and the predicate clitic pronoun lo, as in Maria è simpatica, e anche Giovanna lo è 'Maria is nice, and so is Giovanna' (Cardinaletti \& Repetti 2007, 2008). ${ }^{21}$

The proposal that the quality of the paragogic vowel is influenced by morphological considerations conflicts with Consistency of Exponence, one of the principles underlying the Theory of Gen in Optimality Theory (McCarthy \& Prince 1993: 20-21). ${ }^{22}$ Consistency of Exponence constrains the morphology-phonology relationship so that, among other things, a morphological affiliation of an epenthetic segment is forbidden. In other words, an epenthetic segment posited by Gen will be part of a prosodic constituent, but it will not have a morphological affiliation. However, there is a growing body of literature which shows that epenthetic material can have a morphological interpretation (Kurisu 2001) and that the quality of an epenthetic element can be influenced by morphological considerations (Kavitskaya 2005, Paradis \& Prunet 1989, Rice 2003, Tranel \& Del Gobbo 2002, Vanelli 1992, and others). Kurisu (2001: 34) shows that schwa epenthesis in Upriver Halkomelem denotes continuative aspect; Kavitskaya (2005) reports that in Czech borrowed nouns that are phonotactically acceptable may nonetheless be assigned a final nonetymological [a] so as to be assigned to a particular declension class; Paradis \& Prunet (1989: 334) claim that epenthesis of [u] and [i] in Fula is «morphologically conditioned»; Rice (2003) argues that in Norwegian dialects epenthesis with imperatives ending in a cluster of rising sonority is influenced by morphology; Tranel \& Del Gobbo (2002) and Vanelli (1992) argue that the lo allomorph of the Italian masculine singular definite article derives from /1/ through the insertion of a special epenthetic vowel, [o], whose quality is morphologically influenced.

The proposal suggested here (adopted from Cardinaletti \& Repetti 2007, 2008) is in line with these studies. In particular, I propose that final [o] is used in these contexts specifically because it is morphologically neutral, «the vowel with the lowest information content» (Hume \& Bromberg 2005: 3) in word-final position.

20. Ferrari (2005: 150) makes the opposite argument: final [o] in masculine singular nouns is analyzed as a marker of agreement, while [e] is not. She supports this assertion with the claim that in «grammatical contexts where the end vocalic segment is obligatorily reanalyzed morphologically as the marker of agreement» such as possessive and demonstrative pronouns and past participles, [o] is found, but [e] is not.

21. Note also that other vowels are found word-finally with non-inflecting words - prima 'before', sempre 'always', ogni 'each' - although this list is significantly smaller. Thanks to one of the reviewers for noting this.

22. Alternatives to Consistency of Exponence have been proposed by Walker \& Feng (2004) and others. 
Another vowel, such as [i], that is morphologically marked, is, for this reason, not used in this context. In the next section I support this proposal with data from compounds and affixed words.

\section{Linking elements in compounds and affixoids}

Relevant to the discussion of epenthetic vowel quality is the question of «linking elements» in compounds ${ }^{23}$ and affixoids. ${ }^{24}$ In Italian an [i] or [o] linking vowel may be used between the two elements of a compound and before/after an affixoid.

We begin with a discussion of compounds in Italian (Bisetto 2004, De Dardel \& Zamboni 1999, Iacobini 2004a, Peperkamp 1997, Scalise 1992, Zamboni 1990). When two words are combined to form a compound, a linking element - [i] or [o] - may used between the words.

(15) a. petto + rosso > pettịrosso

'breast' + 'red' > 'robin redbreast'

b. dieta + terapia $>$ dietoterapia

'diet' + 'therapy' > 'diet therapy'

What determines the choice between [i] and [o] as the linking element? Inherited forms use [i]: fruttivendolo 'greengrocer' < frutta 'fruit' + vendolo 'salesperson' (although this is not an independent word, cf. also erbivendolo 'greengrocer' < erba 'herb' + vendolo, pescivendolo 'fish monger'< pesce 'fish' + vendolo). This linking element was used in Classical Latin compounds: caprimulgus 'goatmilker', uiníuorax 'wine guzzling' (Maiden 1995: 183), and is more common in southern Italian dialects than in Italian (Zamboni 1990). On the other hand, productive compounding utilizes [o] as a linking element (see (15b)). Some compounds allow both linking elements, although the form with [o] seems to be the more common one: altipiano/altopiano 'plateau' ${ }^{25}$

Similar to compounds, linking elements are used with prefixoids and suffixoids (Dressler \& Merlini Barbaresi 1991, Iacobini 2004a, 2004b, 2011, Thornton 1996, 2007). Affixoids of Latin and Greek origin come with their own lexically specified vowels, [i] and [o], respectively. ${ }^{26}$

23. For a list of languages which utilize linking elements in compounds, see Linguist List (1999).

24. 'Affixoid' refers to a prefix or suffix derived from a Latin or Greek word.

25. Thornton ( $\mathrm{pc}$ ) points out that altipiano is a back-formation from the plural form with double plural marking: altipiani.

26. The suffix -metro, of Greek origin, uses both linking vowels: acidimetro 'acid meter', salinometro 'salinity measurer', parchimetro/parcometro 'parking meter'. 


\begin{tabular}{|c|c|c|}
\hline \multirow[t]{4}{*}{ (16) } & Latin prefixoids: [i] & Latin suffixoids: [i] \\
\hline & $\begin{array}{l}\text { agri- (agriturismo 'agro-tourism) } \\
\text { quadri- (quadrifoglio 'four-leaf clover') }\end{array}$ & $\begin{array}{l}\text {-ifugo (zanzarifugo 'bug spray') } \\
\text {-ịcida (spermicida 'spermicide') }\end{array}$ \\
\hline & Greek prefixoids: [o] & Greek suffixoids: [o] \\
\hline & $\begin{array}{l}\text { idro- (idrodepurazione 'hydro-purification') } \\
\text { bio- (bioingegneria 'bioengineering') }\end{array}$ & $\begin{array}{l}\text {-ologia (mariologia 'study of Mary') } \\
\text { - } \underline{\text { oteca }} \text { (birroteca 'beer hall') }\end{array}$ \\
\hline
\end{tabular}

What happens if a Latin prefixoid combines with a Greek suffixoid, and vice versa a Greek prefixoid and a Latin suffixoid form a word? Which linking vowel surfaces? ${ }^{27}$ It is always the [o] linking element that appears.

(17) a. Latin prefixoid + Greek suffixoid agri- + - -ologia > agrologia (*agrilogia) 'agrology'

b. Greek prefixoid + Latin suffixoid idro- + - ifugo > idrofugo (*idrifugo) 'waterproof'

With compounds, prefixoids, and suffixoids, the [o] linking element is more productively used than [i]. Migliorini (1963) suggests that it is 'an imitation' of the -o- from Greek, but I propose that this is another example of the use of [o] in a morphologically salient position when a neutral suffix is needed.

\section{Conclusions}

In conclusion, we have seen that there is no single vowel that can clearly be identified as the epenthetic vowel in Italian. We find [i] used predominantly in non-final position, while $[\mathrm{e}] /\left[{ }^{2}\right] /\left[^{\circ}\right]$, [o], and [a] are attested word-finally. We have provided an explanation of the choice of each vowel.

(18) epenthetic vowels in Italian

- [i] is the default phonological epenthetic vowel used in non-final position

- $[\mathrm{e}] /\left[{ }^{2}\right] /\left[^{2}\right]$ is used after consonant-final loans in some non-standard varieties of Italian; it is the result of the release of the word-final consonant

- $[0] /[a] /[\mathrm{e}]$ are selected for morphological reasons with consonant-final borrowed nouns (and adjectives); they are word markers which allow the borrowed noun (or adjective) to be integrated into a declension class; note that this [e] is different from the one above

- $[0]$ is the vowel used at the end of a morphological domain (word, prefix) when no inflectional interpretation is needed; note that this [o] is different from the one above

The lack of consistency in the epenthetic vowels used in different contexts the phonological default vowel is [i], the vocalic element following the release of

27. For vowel-vowel sequences in Italian, see Garrapa (2009). 
a final consonant is interpreted as $[\mathrm{e}] /\left[{ }^{\circ}\right] /\left[^{\circ}\right]$, the morphologically unmarked vowel is [o] - is also found in Spanish where there is «lack of correspondence among default values in different categories of elements»: the morphological default class is class I, the default word marker is /o/, and the phonological default vowel is [e] (Harris 1992: 82).

In this paper, we have seen that there is no single epenthetic vowel in Italian. Through an in-depth study of recent and historical loan word integration we have determined that the choice of the inserted vowel is influenced not only by phonology, but by phonetics and morphology as well.

\section{References}

Acquaviva, Paolo (2009). «The structure of the Italian declension system». In: Montermini, Fabio; Boyé, Gilles; Tseng, Jesse (eds.). $6^{\text {th }}$ Décembrettes: Morphology in Bordeaux, 50-62. http://www.lingref.com/cpp/decemb/6/paper2235.pdf.

Alderete, John (1999). «Head depenence in stress-epenthesis interaction». In: Hermans, Ben; van Oostendorp, Marc (eds.). The derivational residue in phonological Optimality Theory. Amsterdam: John Benjamins, pp. 29-50.

Aronoff, Mark (1994). Morphology by itself. Cambridge, MA: MIT Press.

Avram, Andrei (2010). «The epenthetic and paragogic vowels of Pijin». In: Chruszczewski, P.; Wasik, Z. (eds.). Language in Contact. Wroclaw: Philological School of Higher Education, pp. 7-34.

Bafile, Laura (1999). «Antepenultimate stress in Italian and some related dialects: metrical and prosodic aspects». Rivista di Linguistica 11: 201-229.

Battistella, Edwin (1990). Markedness: The Evaluative Superstructure of Language. Albany, NY: SUNY Press.

Bertinetto, Pier Marco; Loporcaro, Michele (2005). «The sound pattern of Standard Italian, as compared with the varieties spoken in Florence, Milan and Rome». Journal of the International Phonetic Association 35: 131-151.

Bertinetto, Pier Marco (1985). «A Proposito di alcuni recenti contributi alla prosodia dell'italiano». Annali della Scuola Normale Superioore di Pisa (serie 3) 15: 581-643.

Bertoletti, Nello (2003). «Per la conoscenza del veronese antico: allestimento di una raccolta di testi pratici». (unpublished manuscript).

Bisetto, Antonietta (2004). «Composizione con elementi italiani». In: Grossmann, Maria; Rainer, Franz (eds.). La formazione delle parole in italiano. Tübingen: Niemeyer, pp. 31-51.

Broselow, Ellen (1999). «Stress-epenthesis interactions» (unpublished manuscript).

Cardinaletti, Anna; Repetti, Lori (2007). «Vocali epentetiche nella morfologia dell'italiano e dei dialetti italiani». In: Maschi, Roberta; Penello, Nicoletta; Rizzolatti, Piera (eds.). Miscellanea di studi linguistici offerti a Laura Vanelli da amici e allievi padovani. Udine: Forum Editrice, pp. 116-126.

Cardinaletti, Anna; Repetti, Lori (2008). «The Phonology and Syntax of Preverbal and Postverbal Subject Clitics in Northern Italian Dialects». Linguistic Inquiry 39: 523-563.

Cortelazzo, Manlio; Zolli, Paolo (1979-1988). Dizionario etimologico della lingua italiana. Bologna: Zanichelli. 
D'Achille, Paolo; Thornton, Anna (2003). «La flessione del nome dall'italiano antico all'italiano contemporaneo». In: Maraschio, Nicoletta; et al. (eds.). Italia Linguistica Anno Mille - Italia Linguistica Anno Duemila: Atti del XXXIV Congresso Internazionale di Studi della SLI. Roma: Bulzoni.

Dardano, Maurizio (1986). «The Influence of English on Italian». In: Viereck, W.; Bald, W. (eds.). English in contact with other languages. Budapest: Adamdémiai Kiadó, pp. 231-252.

Danesi, Marcel (1985). Loanwords and Phonological Methodology. Ottawa: Didier.

De Dardel, Robert; Zamboni, Alberto (1999). «L'interfixe -I- dans les composés protoromans. Une hypothése de travail». Revue de linguistique romane 63: 439-469.

D’Imperio, Mariapaola; Rosenthall, Sam (1999). «Phonetics and phonology of main stress in Italian». Phonology 16: 1-28.

Dressler, Wolfgang; Merlini Barbaresi, Lavinia (1991). «Interradical interfixes: contact and contrast». In: Ivir, Vladimir; Kalogjera, Damir (eds.). Languages in Contact and Contrast. Berlin \& NY: Mouton de Gruyter, pp. 133-145.

Dressler, Wolfgang; Thornton, Anna (1996). «Italian Nominal Inflection». Wiener Linguistische Gazette 57-59: 1-26.

Ferrari, Franca (2005). A Syntactic Analysis of the Nominal Systems of Italian and Luganda: How Nouns Can Be Formed in the Syntax. NYU, PhD dissertation.

Garrapa, Luigia (2009). Vowel elision in Florentine Italian. Universität Konstanz, PhD dissertation.

Gouskova, Maria; Hall, Nancy (2009). «Acoustics of Epenthetic Vowels in Lebanese Arabic». In: Parker, Steve (ed.). Phonological Argumentation: Essays on Evidence and Motivation. London: Equinox, pp. 203-225.

Hagstrom, Paul (1997). «Contextual Metrical Invisibility and Weak Vowels». Proceedings of the 33 ${ }^{\text {rd }}$ Chicago Linguistic Society. Chicago: Chicago Linguistic Society.

Hajek, John; Stevens, Mary; Webster, Georgia (2007). «Vowel duration, compression and lengthening in stressed syllables in Italian». Proceedings of the International Congress of Phonetic Sciences (ICPhS). Saarbrücken, Germany, pp. 1057-1060.

Hall, Nancy (2006). «Cross-linguistic patterns of vowel intrusion». Phonology 23: 387-427.

Hall, Nancy (2011). «Vowel Epenthesis». In: van Oostendorp, Marc; Ewen, Colin J.; Hume, Elizabeth; Rice, Keren (eds.). The Blackwell Companion to Phonology. Malden, MA \& Oxford: Wiley-Blackwell, pp. 1576-1596.

Harris, James (1991). «The Exponence of Gender in Spanish». Linguistic Inquiry 22: 27-62.

Harris, James (1992). «The form classes of Spanish substantives». Yearbook of Morphology 65-88.

Henderson, Janette; Repp; Bruno (1982). «Is a Stop Consonant Released when Followed by Another Stop Consonant?». Phonetica 39: 71-82.

Hudson, Grover (1995). «Consonant release and the syllable». Linguistics 33: 655-672.

Hudson, Grover (2001). «Amharic Epenthesis». In: Zaborski, Andrezej (ed.). New Data and New Methods in Afroasiatic Linguistics: Robert Hetzron in memoriam. Wiesbaden: Harrassowitz Verlag, pp. 65-73.

Hume, Elizabeth; Bromberg, Ilana (2005). «Predicting Epenthesis: An InformationTheoretic Account». 7th Annual Meeting of the French Network of Phonology Aix-en-Provence, June 2005. 
Hurch, Bernhard; Tonelli; Livia (1982). «/'matto/ oder /' mat:o/? Jedenfalls ['mat:o]». Wiener linguistiche Gazette 29: 17-38.

Iacobini, Claudio (2004a). «Composizione con elementi neoclassici». In: Grossmann, Maria; Rainer, Franz (eds.). La formazione delle parole in italiano. Tübingen: Niemeyer, pp. 69-95.

Iacobini, Claudio (2004b). «Prefissazione». In: Grossmann, Maria; Rainer, Franz (eds.). La formazione delle parole in italiano. Tübingen: Niemeyer, pp. 97-163.

Iacobini, Claudio (2011). «Foreign word-formation in Italian» (unpublished manuscript). Jones, Michael Allan (1997). «Sardinian». In: Maiden, Martin; Parry, Mair (eds.). The Dialects of Italy. London \& New York: Routledge, pp. 376-384.

Kavitskaya, Darya (2005). «Loan Words and Declension Classes in Czech». In: Booij, Geert; et al. (eds.). Morphology and Linguistics Typology (on-line Proceedings of the Mediterranean Morphology Meeting), pp. 267-276.

Kenstowicz, Michael (2010). «Vocale incerta, vocale aperta». Studi e saggi linguistici 48: 1-37.

Kim, Kyumin; Kochetov, Alexei (2011). «Phonology and phonetics of epenthetic vowels in loanwords: Experimental evidence from Korean». Lingua 121: 511-532.

Kitto, Catherine; de Lacy, Paul (1999). «Correspondence and epenthetic quality». In: Kitto, Catherine; Smallwood, Carolyn (eds.). Proceedings of AFLA (Austronesian Formal Linguistics Association) VI. Toronto: Toronto Working Papers in Linguistics, pp. 181-200.

Klajn, Ivan (1972). Influssi inglesi nella lingua italiana. Firenze: Olschki.

Krämer, Martin (2009). The Phonology of Italian. Oxford: OUP.

Kurisu, Kazutaka (2001). The Phonology of Morpheme Realization. UCSD, PhD dissertation.

Lepschy, Anna Laura; Lepschy, Giulio (1981). La lingua italiana: storia, varietà dell'uso, grammatica. Milano: Bompiani.

Linguist List (1999). «Sum: Linking Elements in Compounds»10.1477 http://linguistlist.org/issues/10/10-1477.html (retrieved September 13, 2011).

Lombardi, Linda (ms). «Markedness and the typology of epenthetic vowels». ROA \#578.

Loporcaro, Michele (2002). «Unveiling a masked change: behind vowel harmony in the dialect of Claro». In: Sounds and systems: studies in structure and change. Berlin: Mouton de Gruyter, pp. 75-90.

Maiden, Martin (1995). A Linguistic History of Italian. London \& NY: Longman.

McCarthy, John; Prince, Alan (1993). «Prosodic Morphology» (unpublished manuscript).

Menarini, Alberto (1939). «L'italo-americano degli Stati Uniti». Lingua nostra 1: 152-160.

Migliorini, Bruno (1963). «I Prefissoidi». In: Saggi sulla lingua del Novecento. Firenze: Sansoni, pp. 9-60.

Paradis, Carole (1992). Lexical Phonology and Morphology: The Nominal Classes in Fula. New York: Garland.

Paradis, Carole; Prunet, Jan-François (1989). «On coronal transparency». Phonology 6: 317-348.

Passino, Diana (2005). Aspects of consonantal lengthening in Italian. University of Padua, PhD dissertation. 
Peperkamp, Sharon (1997). Prosodic Words (HIL dissertations 34). Den Haag: Holland Academic Graphics.

Rando, Gaetano (1970). «The Assimilation of English Loan-Words in Italian». Italica 47: 129-142.

Renzi, Lorenzo (1993). «Da dove viene l'articolo il». In: Kramer, J.; Plangg, G. A. (eds.). Verbum Romanicum: Festschrift für Maria Iliescu. Hamburg: Helmut Buske, pp. 215-230.

Repetti, Lori (2006). «The Emergence of Marked Structures in the Integration of Loans in Italian». In: Gess, Randall S.; Arteaga, Deborah (eds.). Historical Romance Linguistics: Retrospective and Perspectives. Amsterdam \& Philadelphia: John Benjamins, pp. 209-239.

Repetti, Lori (2008). «The Masculine Singular Definite Article in Italian» (unpublished manuscript).

Repetti, Lori (2009). «Gemination in English Loans in American Varieties of Italian». In: Calabrese, Andrea; Wetzels, W. Leo (eds.). Loan Phonology. Amsterdam \& Philadelphia: John Benjamins, pp. 225-239.

Rice, Curt (2003). «Dialectal variation in Norwegian imperatives». Nordlyd 31: 372-384.

Rohlfs, Gerhard (1966). Grammatica storica della lingua italiana e dei suoi dialetti: Fonetica. Torino: Einaudi.

Rohlfs, Gerhard (1968). Grammatica storica della lingua italiana e dei suoi dialetti: Morfologia. Torino: Einaudi.

Rose, Yvan; Demuth, Katherine (2006). «Vowel epenthesis in loanword adaptation: Representational and phonetic considerations». Lingua 116: 1112-1139.

Sampson, Rodney (2010). Vowel Prosthesis in Romance: A Diachronic Study. Oxford: OUP.

Savard, Mélanie (2007). Nativisation phonologique et importations dans les emprunts anglais nord-américains en italien calabrais: données statistiques et implications théoriques. Université Laval, $\mathrm{PhD}$ dissertation.

Scalise, Sergio (1992). «Compounding in Italian». Rivista di linguistica 4: 175-199.

Seneca, Pasquale (1927). Il Presidente Scoppetta. Copyright by Pasquale Seneca.

Steriade, Donca (1995). «Underspecification and markedness». In: Goldsmith, John A. (ed.). The Handbook of Phonological Theory. Oxford: Blackwell, pp. 114-174.

Thornton, Anna (1996). «On some phenomena of prosodic morphology in Italian: accorciamenti, hypocoristics and prosodic delimitation». Probus 8: 81-112.

Thornton, Anna (2001). «Some Reflections on Gender and Inflectional Class Assignment in Italian». In: Schaner-Wolles, C.; et al. (eds.). Naturally! Linguistic Studies in Honour of Wolfgang Ulrich Dressler Presented on the Occasion of his 60th Birthday. Torino: Rosenberg \& Sellier, pp. 479-487.

Thornton, Anna (2007). «Phénomènes de reduction en italien». In: Delais-Roussarie, Elisabeth; Labrune, Laurence (eds.). Des sons et des sens. Paris: Lavoisier, pp. 241-268.

Tranel, Bernard; Del Gobbo, Francesca (2002). «Local Conjunction in Italian and French Phonology». In: Wilshire, Caroline; Camps, Joaquim (eds.). Romance Phonology and Variation. Amsterdam \& Philadelphia: John Benjamins, pp. 191-218.

Uffmann, Christian (2004). Vowel Epenthesis in Loanword Phonology. PhilippsUniversität Marburg, PhD dissertation. 
Uffmann, Christian (2006). «Epenthetic vowel quality in loanwords: Empirical and formal issues». Lingua 116: 1079-1111.

Vanelli, Laura (1992). «Da 'lo' a 'il': storia dell' articolo definito maschile singolare nell'italiano e nei dialetti settentrionali». Rivista italiana di dialettologia 16: 29-66.

Vayra, Mario; Avesani, Cinzia; Fowler, Carol (1999). «On the phonetic bases of vowel-consonant coordination in Italian: A study of stress and compensatory shortening». Proceedings of the International Congress of Phonetic Sciences (ICPhS), pp. 495-498.

Walker, Rachel; Feng, Bella (2004). «A Ternary Model of Morphology-Phonology Correspondence». In: Schmeiser, B.; Chand, V.; Kelleher, A.; Rodriguez, A. (eds.). WCCFL 23 Proceedings. Somerville, MA: Cascadilla Press, pp. 773-786.

Zamboni, Alberto (1988). «Divergences and convergences among Neo-Latin systems in North-Eastern Italy». Folia Linguistica Historica 8: 233-267.

Zamboni, Alberto (1990). «Premesse morfologiche e tipologiche del composto italiano capinera, pettirosso». Parallela 4: morfologia: Atti del V Incontro Italo-Austriaco, pp. 97-109. 